\title{
Thinking with broken glass : making pedagogical spaces of enchantment in the city
}

\section{Pyyry, Noora}

2017

Pyyry, N 2017 , ' Thinking with broken glass : making pedagogical spaces of enchantment in the city ' , Environmental Education Research , vol. 23 , no. 10 , pp. 1391-1401 . https://doi.org/10.1080/13504622

http://hdl.handle.net/10138/326384

https://doi.org/10.1080/13504622.2017.1325448

unspecified

acceptedVersion

Downloaded from Helda, University of Helsinki institutional repository.

This is an electronic reprint of the original article.

This reprint may differ from the original in pagination and typographic detail.

Please cite the original version. 
Reference: Pyyry, N. (2017). Thinking with broken glass: creating pedagogical spaces of enchantment in the city. Environmental Education Research, 23 (10), 13911401 .

\begin{abstract}
In this paper, I explore thinking that happens in children's meaningful engagement with the city. To open up my argument, I discuss two events during which children are caught up in intra-active (Barad 2003) play with things and spaces. I argue that this mode of being joyfully engaged with one's surroundings is key to what Jane Bennett (2001) calls enchantment. This experience can be described as a sudden moment of wonder-at-the-world: it is an inspiring event of being moved by something. It is a disruption that can open up new reflection. Because enchantment is highly affectual, it deepens one's engagement with the world: it fosters $d$ welling with (Ingold 2000). By this, I refer to making a home for oneself in the world, with the world. I approach this engagement and thinking with an acknowledgement of the capacity of the material and non-human world to provoke effects in human bodies: things and spaces thus take part in meaningful everyday encounters that make dwelling with possible. This more-than-human understanding allows for alternative ways of conceptualizing learning. Clean-cut categorizations such as 'learner', 'urban', 'nature', and so on become problematic, and learning is re-conceptualized as an ongoing, nonlinear and rhizomatic event in which knowing and being are always tied together. While playing, children are open to the unexpected: they are dwelling with the city and take part in creating new pedagogical spaces of enchantment (Pyyry 2016a).
\end{abstract}

Keywords: dwelling; enchantment; learning; non-representational theory; play; urban space

\title{
Being enchanted is passion about dwelling with the world
}

I will start my discussion with a mundane event from San Francisco, California, where I was doing participatory research with tween girls on their urban geographies of hanging out (e.g. Pyyry 2015, 2016). As social science researchers know from experience, academic work can never really be separated into phases of fieldwork and analysis, fieldwork or no fieldwork. In fact, it is often difficult to divide the work into separate projects or detach it from other spheres of life. So, although I was conducting a participatory study with a group of tween girls, the research impacted all of my life. The vignette, which I will soon turn to, was an event that captured my attention, since I was working with Tim Ingold's (2000) concept of dwelling with in order to explore human involvement with the urban landscape. Something happened when I was walking home with my children one day. Looking back, it was a moment of the world speaking back to theory. Consequently, the vignette opens up the argument of this paper particularly well: it suggests that thinking emerges in unforeseen encounters. In 
research, empirics and theoretical analysis always go together, and they get entangled with everything else that is going on. It is in this emergent, rhizomatic relational field that researchers build their understandings (Hultman \& Lenz Taguchi 2010). We know through engaging, through dwelling with the world.

Ergo, with the vignette, I want to illustrate what I think is important in conceptualizing dwelling with, and the openings this involvement can create for enchantment (Bennett 2001). These two inter-linked concepts are essential to how I attend to thinking and learning, to being playful and engaged with the world. In the event that captured my attention in San Francisco, my son noticed broken black glass on the street and stopped to play with it (Figure 1). He was completely caught up in the play, he did not really hear or see anything else that was happening around him. He was feeling the glass in his hands, collecting the pieces and examining them. In this moment, I argue that he was affectually engaged with the street and the glass so that he was becoming something else. He was hence not a single, coherent subject engaging with separate objects, rather I would say he was a coming-together of what was going on there and then. Here, 'the subject' and the 'object' fall on the same side of a shared movement, as Brian Massumi (2011) puts it: they are linked in a joint-experience of movingtoward. This is an event: 'a rolling of subjective and objective components into a mutual participation, co-defining the same dynamic'. Thinking about the world through events carries with it an understanding that the subject and object are always connected. There is no such thing as a 'perceiving subject' outside of the world, rather the subject is created through events, again and again. 


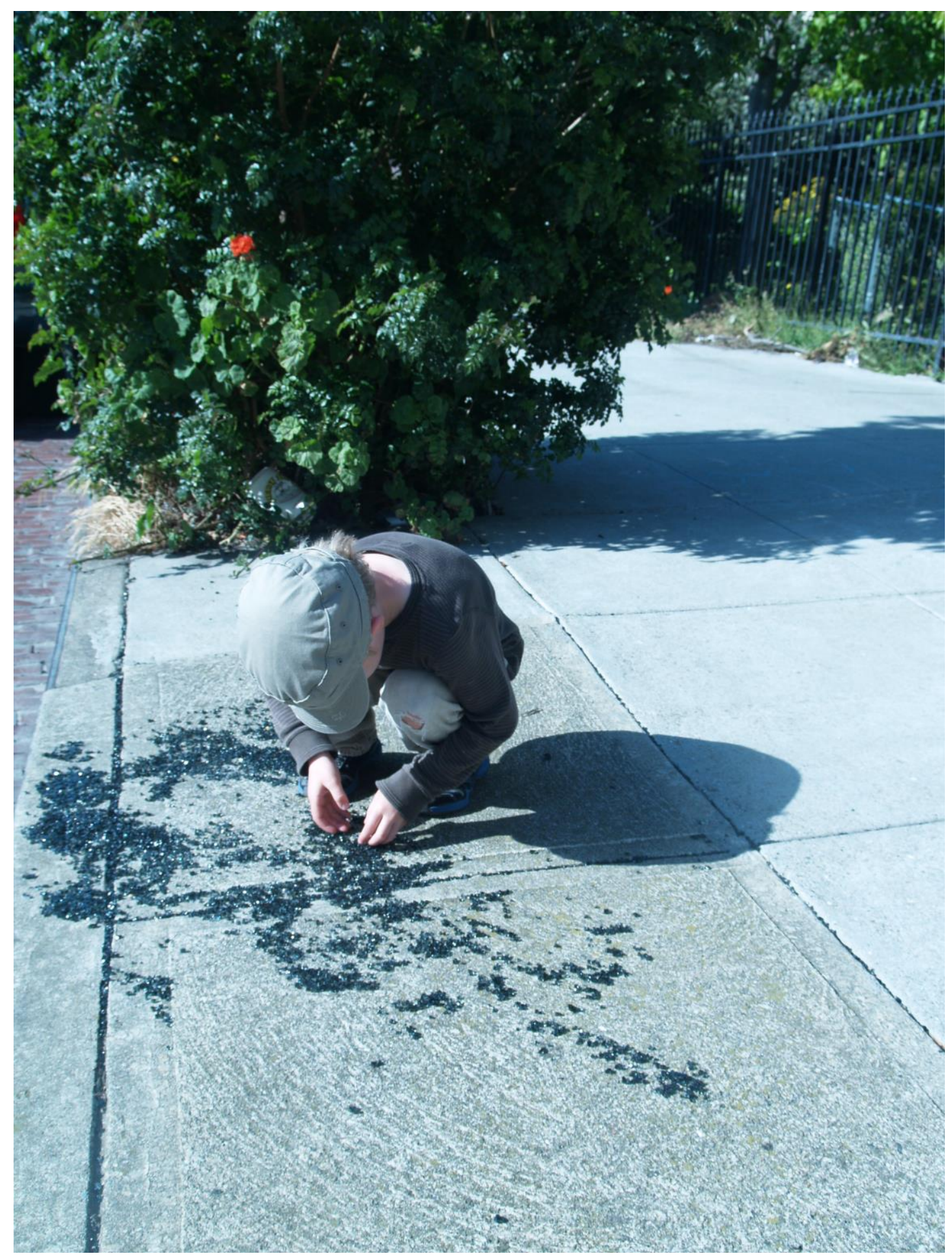

Figure 1. Learning with the city in San Francisco.

While playing with the pieces of glass - or while the glass was playing with him - my son was extremely happy and seemed to be quite in awe of the world, immersed in it. I argue that this mode of being joyfully and meaningfully engaged with spaces and things is key to the unusual experience of enchantment. This is 'dwelling with'. 
In thinking of the transient moment of enchantment, the concept of 'dwelling with' has proved to be valuable (e.g. Pyyry 2016a, 2016b). Dwelling with, as I illustrated with the vignette, refers to being meaningfully engaged with one's material environment, and more broadly with the world. It is making a home for oneself in the world, with the world. Understood this way, dwelling is always connected to building: they are two sides of the same coin (Rose 2012). When 'building' is conceptualized broadly, it includes small passing acts, such as children's everyday spatial appropriations. Through these acts, together with the material and the non-human world, children produce alternative modes of involvement with the city and temporarily claim the world as their own. This clears space for enchantment.

The experience of enchantment is an uplifting delight about being alive. It is a feeling of wonder-at-the-world. Although often connected with joy, it can also be a state of trouble, even fear (Bennett 2001). The broken glass intrigued my son, but it could have also posed questions to him in the form of small pain. So, enchantment does not have to be a pleasant feeling of being connected with the world, the point is that enchantment has a strong affective force. In effect, enchantment is often a moment of simultaneous immersion and disconnect with the world: it's a sort of 'opening-onto' and 'distancingfrom' the world (Wylie 2009). So, it is not only a fusion of self and the world, rather it is both presence and absence at the same time. This unspecific moment of mystery often goes by unnoticed, it is a short-lived juncture that is always already escaping. Is often out of the reach of verbal representation, but it is a powerful force that is felt, you are sort of struck by it when caught up in a moment. So, enchantment is not something we can necessarily pin-point or prove to have happened: it is non-representational.

Because enchantment is highly affectual, it deepens human engagement with the world, with places and things. Enchantment and dwelling, then, nurture each other. Enchantment attunes you to the world differently, it shakes your subjectivity. It is a moment of feeling the world running through you (see Massumi 2000). Hence, Bennett (2001) convincingly argues that enchantment is key to ethical being-in-the-world. So, here is where love comes to the picture: when you are deeply involved with something, you tend to care for it too. This understanding places value to spending time with ordinary, everyday things and spaces. Enchantment is then not so much connected with 
curiosity (obsession with the new), but with genuine wonder (Stone 2006). It emanates from dwelling with, which can be characterized as a sort of opening to the world. Involved activity strengthens the spatial relationship, and respect for the urban environment is built in this process.

In the event of my son engaging with the glass, learning emerged from the jointexperience: the pieces of glass, the street, sounds, scents and everything that came together there and then took part in the event. There was then no individual 'learner', no 'subject' to think the world from outside: thinking happened with the world. Barad (2003, 803) talks about intra-activity, when she discusses the mingling of different elements that do not have clear boundaries. The concept is an important effort to go beyond thinking about the world through boundaries and dichotomies. A piece of glass can take part in intra-active play, from which new spaces can be created. A human body, as all bodies, can then be understood as a fluid, ongoing and relational nexus of flows, inseparable from the rest of the world: it is a coming-together of forces (Grosz 2005). Human agency emerges differently in different situations, since it is never thoroughly an individual affair. Therefore, knowing and learning are understood to take place within the world, with everything that comes together in an event (e.g. Fenwick et a. 2011; Taylor et al. 2013). Although I grant a special role to human intentionality in this paper's argument, my son's body and agency thus emerged differently in this situation than they would have done, for instance, at a playground. Subjectivity is produced in encounters with the world, and it is therefore important to pay attention to the kind of encounters our cities allow for.

\section{'The bubble-wrap generation' is living and learning in tight time-spaces}

'Time is life, and life resides in the human heart. The men in grey knew this better than anyone. Nobody knew the value of an hour or a minute, or even a single second, as well as they. [...] They had designs on people's time - long-term and well-laid plans of their own. What mattered most to them was that no one should become aware of their activities. They had surreptitiously installed themselves in the city.' (Ende 1973/1984)

This quote from Michael Ende's (1973/1984) famous novel, Momo, tells about grey 
men, who are stealing time from humans. The whole city in the story becomes dull, sterile and devoid of all things that are not considered useful. The grey men steal all the fun in the world: they steal the possibility for enchantment. Only Momo, a little girl with extraordinary abilities, can fight them. The child eventually rescues all the people and brings life back to the city.

The vignette of my son engaged in play with the glass can be approached from many points of view. One of these is the increased scheduling and monitoring of children's lives in the name of safety and productivity. It is understandable that many parents would not want their children to play with broken glass on the street. A playground is viewed as much more suited to a young child. Karen Malone (2007) has called children of today 'the bubble-wrap generation' to bring attention to the highly controlled environments children live in, also in their free time. 'Security' is used to justify restrictive policies and practices in urban spaces, and the tightened notions of safety strongly affect children's lives in Western cities (e.g. Pyyry \& Tani 2016). Children's days tend to be scheduled very early on for 'educational' and 'developmental' purposes and parents often end up driving them from one organized activity to another (see Karsten 2005; 'the backseat generation'). As a result, very little time is left for children's independent mobility and free, unplanned experimentation with everyday spaces. Children also quickly internalize shared notions of safety and become more hesitant to explore new spaces. Upsetting news of crimes against children, or horrible stories about accidents that are waiting to happen, further socialize them into the security talk.

When fear guides urban planning and parental decision-making, there is a risk that children are kept supervised at all times in spaces specifically designed for their use (e.g. playgrounds). Aitken (2001) remarks that children are actually spatially outlawed by society in these acceptable 'islands'. Even when playspaces are built for more extreme fun and entertainment, the experience is often designed by authoritarian capitalism - an interesting mix of control through surveillance and distraction through entertainment (Thrift 2011). These spaces cultivate political passivity. And, when people are charged for entering, many children are placed as outsiders. Although playgrounds are often pleasant and convenient places for parents and children to gather in, they take part in the re-production of the prevailing urban order. Playground spaces 
can be effectively used for their designed purpose, but within the functional planning, improvisation often feels unwelcome and children therefore conform to the established norms of movement. If these norms and materialities are taken for granted, children may not have much space for playing with who or how they are. Franck and Stevens (2007) note that even when these types of tight spaces could be used differently, this may not be tolerated by the majority of people. Playgrounds may physically allow for many different kinds of activities, but they tend to be selective in terms of who is invited (according to age etc.) and which ways of being/doing are welcomed. To make these spaces looser would require being differently in them.

Not only do children spend their free time in tight spaces, but often from an early age, they also attend to some form of 'schooling'. Formal education is structured around time-spaces within which it is difficult for anything radically new to emerge. It is obviously artificial to make a division between 'formal' and 'informal' learning environments, since as everything else, these overlap and connect in many ways. Still, despite the skills based reforms that are taking place in many Western countries, the formal educational structures often serve very traditional notions of learning. The aim of this article is not to make a statement about what formal geography or environmental education should look like (for this, see e.g. Lambert et al. 2015; Wadley 2008), but to sketch what learning is in a more-than-human frame and think of how it comes forth in the world. Two aspects are particularly important. The first is the dominant emphasis on learning as something that an individual human body does. He/she acquires information about the world (that is 'out there'). This implies that humans are separate from the world. This separation brings with it a belief that learning can be measured by testing individual performance. Coupled with this is the predominance of relatively fixed and pre-given meanings and normativities of learning as deliberative, useful, discursive, and something that occurs in particular times and places, in a linear manner. Even when learning is understood in a more flexible way, many of the defining structures (e.g. standardized testing) remain. As the vignette in the beginning suggested, there is more to learning than gathering information about the world. Placing the human being in the world means overcoming the subject-object dichotomy that has dominated Western thought for too long. Re-conceptualizing learning in a more-than-human, practice-oriented frame makes it possible to take it as an orientation toward futures, not as an act of distancing (the world from the self). 
This conceptualization gives value to children's everyday practices. It also places importance on children's right to their city. This relates to what Henri Lefebvre (1947/2014) and the avant-garde group Situationists International strived for with their ideal of 'unitary urbanism'. The Situationists saw functionalist urban planning as a threat for spontaneity and wonder, and aimed to shake the urban order with imagination and play (see Knabb 2006). They linked action and understanding in their practices of studying the city, just as children do when playing with interesting materials. Following their thought, children - and all people - should have time and space to engage with urban spaces, to be affected by them. Spatial-embodied transformation comes from everyday practice and involved activity fosters care for the urban environment. The right of access and care for one's city thus go together.

When engaging with broken glass, the surface of the street or other interesting materials, children learn to respond to their environment wisely. Learning happens while being affectually engaged with spaces and things, in intra-active play. This is what Ingold (2000) calls enskilment: learning in everyday practice. Enskilment goes together with place-making, a creative process of engagement with the world that cultivates spatial skills. Because movement and cognition are tied together, this practical knowledge cannot be taught outside the context of use. And, it cannot be measured by tests, such as the PISA (the OECD Programme for International Student Assessment). This is why this multisensory reflection about one's place in the world is not always recognized and valued at a time of security talk and pressures of productivity. It is as if Ende's horrific fantasy-world has come true.

\section{Entangled with 'other' living material and creating new worlds}

My second vignette is from the Oxford University grounds, England. Here (Figure 2), my two children climbed up a stone wall with the help of a tree conveniently growing close to the wall. From a posthuman point of view, the children did not just decide to climb up - rather, the intriguing setup invited them to explore. Bennett (2010) refers to this as thing power: the material and non-human world has a capacity to affect human bodies. This idea entails an acknowledgement of the liveliness that is internal to materiality, i.e. also the stone wall. But, not only did the wall and the tree actively invite 
the children to climb, in the event, they all became something more, something new: the children's bodies, the tree, the wall, ideas of safety, gender or appropriate behavior in the university area, my fear, other people passing by, and much more mingled without clear boundaries. This 'more' includes also things absent at that moment. They all took part in intra-active play from which new worlds (and bodies) are created. This is new knowledge. It emerged relationally, from the mix of human intentionality and the other forces of the world.

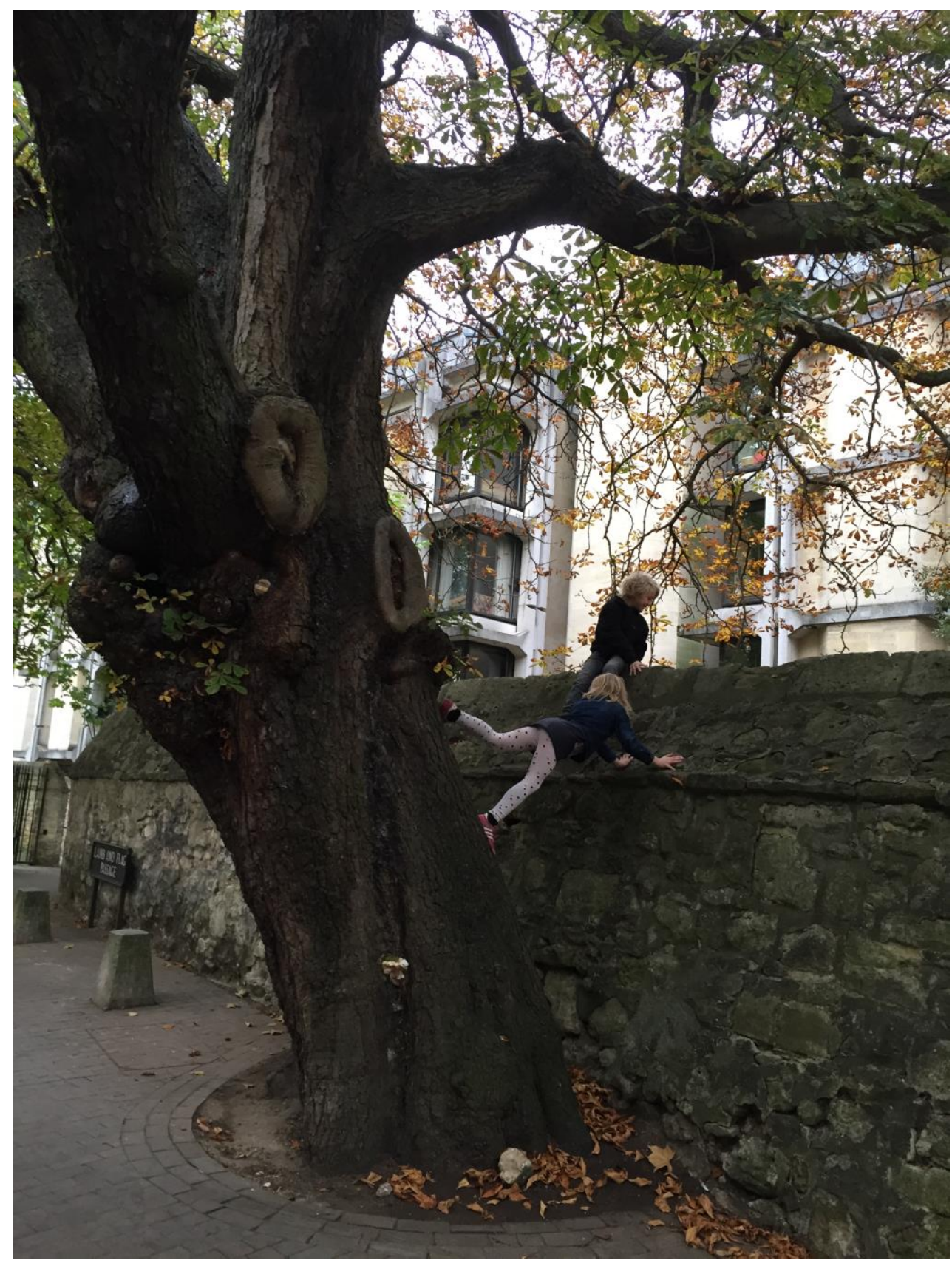

Figure 2. Learning with the city in Oxford, England. 
A relational conceptualization of the world makes rigid categorizations such as 'nature/urban' or 'nature/culture' impossible. The world is understood to be more complex than that. It emerges through events as an ongoing (be)coming-together of multiple things (matter, action, relations). The children-tree-wall combination was a rhizomatic, multidirectional unit of becoming through which agency, power and thinking actualized. Rautio (2013) discusses children's internally rewarding everyday practices, such as carrying stones, to open up how we are continually constituted by other animate or non-animate entities. This means that humans are always nature and culture, and it is impossible to make the division. The children-tree-wall unit was not a stable one, it was an open-ended formation that was also intra-active with everything else taking place then. Effectivity and knowing emerged rhizomatically within the flows of energy in the climbing event. There is, of course, no way of proving that enchantment took place there and then, but the atmosphere of the event that 'vibrated in the air' suggested that something significant happened. There was a burst of joy that came from this joint participation that could also be felt behind the camera. 'Joy' here is understood as something more than just a human psychological state, it is a wave of uplifting ontological energy (Braidotti 2013). This affectual atmosphere and feeling 'points to the possibility that minor variations within and between bodies may generate affective turbulence producing in turn a sense that some kind of difference is in the making', as Derek McCormack $(2013,33)$ puts it. The feeling is non-representational.

Non-representational geography or non-representational theory (NRT; see Anderson \& Harrison 2010; McCormack 2013; Thrift 2008, 2011; Wylie 2009) provides theoretical tools for thinking about learning as a spatial-embodied transformation that is prompted by everyday encounters. This transformation emerges in events and the multiple forces at work cannot be fully captured with verbal description. Attention needs to be paid on the performative and affectual, since representationalism separates the world into the ontologically disjointed realms of words and things (see Barad 2003). This separation pervades the dominant understanding of learning as an individual human project that can be represented with evidence (and thus measured with tests). Non-representational theorization calls for attention to things taking-place: it aims to work beyond representation, because it looks at action as a relational phenomenon. Involvement with the world is habitual rather than 'conscious'. Non-representational theorization thus 
aims to study the multiple spatial processes that are involved in an event, whether or not they cross the threshold of contemplative cognition (McCormack 2003). Emphasis is thus placed on everyday affectual geographies that are often left unnoticed, but through which the world is experienced (e.g. Horton \& Kraftl 2006). For children, an important everyday practice and a way of relating with the world is play.

\section{Towards playful cities}

Children's play has been studied from many perspectives and has been given numerous functional definitions over time, ranging from evolutionary to sociological interpretations (see Sutton-Smith 1997). Often, play has been connected with the development of a child (e.g. Mead 1934; Piaget 1962; Vygotsky 1967). Conceptualizing play with non-representational theory makes it possible to view it as a 'mode' of being in the world, rather than a form of behavior that can be observed from the outside (Thrift 2011). Play is openness towards the world and receptiveness to new ideas: it is a joyous way of engaging with the world. Looked at this way, play is not examined as a means to an (educational or developmental) end; instead it is valued as such. Play is complicated, undefinable and de-individualistic, it consists of many different forms of being (Rautio \& Winston 2015). Most importantly, play is highly affectual, and it therefore holds the capacity to change things. When involved in meaningful playful activities, children are open to the world unfolding, they are open to the complexity of life and the unforeseen. They engage with things and spaces in a non-instrumental, goal-free way. This is why play fosters dwelling with: it is pleasantly purposeless (from an adult point of view) and nomadic. In play, children make the city their playground, and home, through improvisation and experiment.

This connects the discussion to spatial criticism and children's right to the city. Quentin Stevens (2007) talks about 'urban play' when he examines people's spontaneous creative acts and spatial appropriation in the city. Children's urban play and willingness to experiment with their surroundings is just what the Situationists called for when they were hoping for a revolution that would arise from everyday life. Play carries with it power to open up space for enchantment and everyday politics, for re-thinking the city and for transformation of space. In play, children speak back to the adult world: they imagine new ways of engaging with it. Play thus entails potential for being otherwise. 
Children's urban play makes possible futures and ways of being visible to the rest of us, just as Momo, the little girl in Ende's story does with a help of her turtle-friend. Children invite us to fight the grey, time-stealing vampires of neoliberal everyday life by letting ourselves be caught up in a moment of enchantment (also Duhn 2016). Children dwell with the city, claim it as their own, and change it though small acts of 'building'.

The event of intra-active play in the Oxford University grounds re-worked the space, even if just momentarily. Through the playful encounter, the children challenged the routine ways of movement there. Spaces of learning with the city can be conceptualized as experiments with the world that is continually in-the-making. This conceptualization draws attention to the disjointed and emergent nature of learning. By shifting the attention away from the individual knowing subject, learning is reconceptualised as a non-linear and multidirectional process, it is a complex coming-together of things taking place then and there (also Fors et al. 2013). In the event of climbing, action and reflection was provoked by the encounter with the non-human. The feel of different surfaces and other living material invited the children to intra-active play from which new pedagogical spaces of enchantment can emerge (Pyyry 2016a). Learning happened through dwelling with the city: it was spatial-embodied. This links to what I have elsewhere conceptualized as 'hanging out -knowing': an ongoing process of reflection about one's place in the world that takes place in everyday encounters (Pyyry 2016a). In a more-than-human frame, learning is an event of 'dwelling with enchantment - reflection'. Many things take part in the event, and learning does not evolve in a temporal order. Rather, new knowledge emerges surprisingly. Involvement and being playful is important here, since joy inspires imagination and can take learning to new directions. Engaging with spaces and things makes it possible to see the world anew and to produce new means of association. It makes is possible to think that which cannot be verbalized.

Conceptualized this way, learning is as life: it exceeds categories and simple definitions. Something always escapes. Learning via enchantment is fueled by the excess and complexity of the world. Enchantment is a moment when familiar things appear odd, even surreal, and it therefore opens up questions, about how things stand (Bennett 2001). Enchantment can never be predicted - it is always accidental - but by 
supporting children's spontaneous playfulness in cities, space can be cleared for the inspiring experience. This unspecific event of being moved by something provokes awareness of how the world is framed, of how it works - and most importantly, makes it possible to imagine how it could be.

\section{Reflections}

The argument of this paper is based on the recognition that knowing exceeds individual human beings: it is much more than a human issue. Rather than viewing the human being as a curious world-molding subject, the world poses questions to us as we go with it. Knowing takes place in shared movement, and our subjectivities are always connected to what is going on. New reflection on urban matters becomes possible through dwelling with the city and emerges in affectual moments of enchantment, which in turn, deepen one's relationship with the world. In an event of 'dwelling with - enchantment - reflection', one is somehow differently attuned to being. This experience of not-understanding (wonder) takes time and space. Learning with the city is thus closely connected to questions of spatial politics, right to the city and care for the world. A more-than-human approach ties together action and reflection by placing the human subject firmly in the world, and hence supports critical environmental education practice, which faces tremendous challenges in today's world (e.g. Payne 2016).

When children have time and space to engage with the urban environment, they are often caught up in imaginative intra-active play with trees, stones or just broken glass on the street. In these moments, they seem to be immersed in the world, or at least deeply engaged with it: intrigued, puzzled and inspired. I argue that this receptive mode of being playfully engaged with everyday spaces and things makes it possible to be genuinely moved by the world. This highly affectual experience of enchantment is a disruption that can open up new reflection. Enchantment can be prompted by the strange and the novel, but most often it arises from encounters with the very ordinary. Something happens, sort of hits you: this is the force of the world. The moment opens up questioning, modest or profound, and produces new ways of being. New knowledge emerges. Moments of enchantment are always accidental, but by letting children wander and wonder - by letting them dwell with their cities - space is cleared for the 
inspiring experience. Then, children have a chance to question the routine, fleeting and taken-for-granted aspects of urban life. Through this, they become enskilled urban dwellers. When given time and space to do so, children experiment with what is intriguing, what is scary, what is dull - and, most importantly with how the world could be. Many things come together in these events of experimentation: materials, energy, human and non-human bodies, feelings of fear, excitement, joy and more, memories, ideas, hopes and wishes - also people and things absent affect the situations (this includes ideologies and hidden attitudes). Sensing and thinking emerge in the encounters, relationally. As [enter EER citation here] in the previous paper of this Special Issue points out, it is crucial to recognize all different agents affecting children's urban geographies, so that these can be taken into account in formal education and policy making.

The vignettes I introduced in this paper may provoke discussion about safe and childfriendly urban spaces. I hope it will not emerge in the form of 'security talk', since within tight urban spaces and highly structured everyday lives, children have few chances to experiment with different ways of being-in-the-world. They have very few chances for creating their own pedagogical spaces of enchantment. By paying attention to the ways in which learning emerges relationally in complex and non-linear ways, it is possible to acknowledge and respect the countless ways in which children already know. And, it is possible to appreciate their desire to learn more. I therefore wish for adults to work hard on making space for children's alternative modes of experimentation with the city. Even, and especially, when this may not seem very clean or convenient. This call for attention is not meant as an attempt to integrate children's urban geographies into the educational system in any instrumental way, although it is possible to link schoolwork to children's creative means of exploring their city. Spatialembodied knowing can be articulated at school through art, writing, drama or imaginative mapping of urban spaces that matter to children.

Child-friendly urban spaces are loose spaces: they allow for children to engage in intraactive play with spaces and things, and with other living material. Child-friendly spaces allow children to be otherwise. But, children also create these spaces. When engaged meaningfully with the material and the non-human world, children momentarily claim spaces as their own. They are linked with the city in an experience of joint-participation 
from which everyday politics emerges. Through small and momentary practices, children question the rules of appropriate behavior and prevailing ideas of safety in the city, and through this, carve space for alternative ways of being. By dwelling with urban spaces children express what is important to them (see Rautio \& Jokinen 2015). And, by probing the limits of everyday life, children make the city more interesting for adults, as well. They make space for diversity, spontaneity and playfulness. This is why the conceptualization of learning introduced in this paper is not only relevant to educators and parents, it is also an urgent call to urban planners to re-think what cities could be: places of openness and enchantment, provocation, (com)passion and generosity.

\section{Acknowledgements}

This work has been funded by the Kone Foundation.

\section{References:}

Aitken, S.C. 2001. Geographies of young people: The morally contested spaces of identity. London: Routledge.

Anderson, B., and P. Harrison, eds. 2010. Taking-Place: Non-Representational Theories and Geography. Farnham: Ashgate.

Anderson, B. and Wylie, J. 2009. On Geography and Materiality. Environment and Planning A, 41 (2), 318-335.

Barad, K. 2003. Posthumanist performativity: Toward an understanding of how matter comes to matter. Signs: Journal of Women in Culture and Society 28 (3), 801-831.

Bennett, J. 2001. The enchantment of modern life: Attachments, crossings, and ethics. Princeton: Princeton University Press.

Bennett, J. 2010. Vibrant matter: A political ecology of things. Durham: Duke University Press.

Duhn, I. 2016. Speculating on childhood and time, with Michael Ende's Momo (1973). Contemporary Issues in Early Childhood, 17 (4) 377-386.

Ende, M. 1973/1984. Momo. (Original work Momo published in 1973.) Translation by Brownjohn, J.M. New York: Penguin books.

Fenwick, T., R. Edwards, and P. Sawchuk 2011. Emerging approaches to educational research: Tracing the sociomaterial. London: Routledge. 
Fors, V., Å. Bäckström, and S. Pink 2013. Multisensory emplaced learning: Resituating situated learning in a moving world. Mind, Culture, and Activity, 20, 170-183.

Franck, K.A., and Q. Stevens 2007. Tying down loose space. In Loose space: Possibility and diversity in urban life, edited by K. A. Franck, and Q. Stevens, 54 72. London: Routledge.

Grosz, E. 2005. Time travels: Feminism, nature, power. Durham and London: Duke University Press.

Horton, J., and Kraftl, P. 2006. Not just growing up, but going on: Materials, spacings, bodies, situations. Children's Geographies, 4 (3), 259-276.

Hultman, K., and Lenz Taguchi, H. 2010. Challenging anthropocentric analysis of visual data: A relational materialist methodological approach to education research. International Journal of Qualitative Studies in Education, 23 (5), 525542.

Ingold, T. 2000. The Perception of the Environment: Essays on Livelihood, Dwelling and Skill. London: Routledge.

Karsten, L. 2005. It all used to be better? Different generations on continuity and change in urban children's daily use of space. Children's Geographies, 3, 275290.

Knabb, K. 2006 (ed.). Situationist International: Anthology. Berkeley: Bureau of Public Secrets.

Lambert, D., Solem, M., and Tani, S. 2015. Achieving human potential through geography education: A capabilities approach to curriculum making in schools, Annals of the Association of American Geographers, 105, 4, 723-735.

Lefebvre, H. 1947/2014. Critique of everyday life. The one-volume edition. (Original texts of Critique de la vie quotidienne published in 1947, 1961 and 1981.) Preface by M. Trebitsch, translation by J. Moore, and G. Elliott. London: Verso.

McCormack, D.P. 2003. An event of geographical ethics in spaces of affect. Transactions of the Institute of British Geographers, 28 (4), 488-507.

McCormack, D.P. 2013. Refrains for moving bodies. Experience and experiment in affective spaces. Durham and London: Duke University Press.

Malone, K. 2007. The bubble-wrap generation: Children growing up in walled gardens. Environmental Education Research, 13 (4), 513-527.

Massumi, B. 2000. The ether or your anger: Towards a pragmatics of the useless. In The pragmatist imagination: Thinking about things in the making, edited by $\mathrm{J}$. Ockman, 160-167. Princeton: Princeton Architectural Press.

Massumi, B. 2011. Conjunction, Disjunction, Gift. Transversal. A multilingual 
webjournal. http://eipcp.net/transversal/0811/massumi/en

Mead, G. H. 1934. Mind, self, and society. Chicago: University of Chicago Press.

Payne, P. G. 2016. What next? Post-critical materialisms in environmental education. The Journal of Environmental Education, 47 (2), 169-178.

Piaget, J. 1962. Play, dreams, and imitation in childhood. New York: Norton.

Pyyry, N. 2015. 'Sensing with' photography and 'thinking with' photographs in research into teenage girls' hanging out. Children's Geographies, 13 (2), 149-163.

Pyyry, N. 2016a. Learning with the city via enchantment: photo-walks as creative encounters. Discourse: Studies in the Cultural Politics of Education, 37 (1), 102115.

Pyyry, N. 2016b. Participation by being: Teenage girls' hanging out at the shopping mall as 'dwelling with' [the world]. Emotion, Space and Society, 18, 9-16.

Pyyry, N., and S. Tani 2016. Young people's play with urban public space:

Geographies of hanging out. In B. Evans and J. Horton (eds.) Play, Recreation, Health, and Wellbeing, Vol. 9 of Geographies of children and young people, edited by T. Skelton. Singapore: Springer.

Rautio, P. 2013. Children who carry stones in their pockets: on autotelic material practices in everyday life. Children's Geographies, 11 (4), 394-408.

Rautio, P., and Jokinen, P. 2015. Children's relations to the more-than-human world beyond developmental views. In Evans, B. and Horton, J. (eds.) Play, Recreation, Health, and Wellbeing, Vol. 9 of Geographies of children and young people, edited by T. Skelton. Singapore: Springer.

Rautio, P., and Winston, J. 2015. Things and children in play-Improvisation with language and matter. Discourse: Studies in the Cultural Politics of Education, 36 (1), 15-26.

Rose, M. 2012. Dwelling as marking and claiming. Environment and Planning D: Society and Space, 30 (5), 757-771.

Stevens, Q. 2007. The ludic city: Exploring the potential of public spaces. London: Routledge.

Stone, B. E. 2006. Curiosity as the thief of wonder: An essay on Heidegger's Critique of the ordinary conception of time. KronoScope, 6 (2), 204-229.

Sutton-Smith, B. 1997. The ambiguity of play. Cambridge, Massachusetts: Harvard University Press.

Taylor, A., M. Blaise, and M. Giugni 2013. Haraway’s 'bag lady story-telling': Relocating childhood and learning within a 'post-human landscape'. Discourse: 
Studies in the Cultural Politics of Education, 34 (1), 48-62.

Thrift, N. 2008. Non-representational theory: space/politics/affect. London: Routledge.

Thrift, N. 2011. Lifeworld Inc - and what to do about it. Environment and Planning D: Society and Space, 29, 5-26.

Vygotsky, L. S. 1967. Play and its role in the mental development of the child. Journal of Russian \& East European Psychology, 5 (3), 6-18.

Wadley, D. A. 2008. The garden of peace. Annals of the Association of American Geographers, 98 (3), 650-85.

Wylie, J.W. 2009. Landscape, absence and the geographies of love. Transactions of the Institute of British Geographers, 34 (3), 275-289. 